\title{
TERRA INCOGNITA
}

DOI: $\underline{10.17805 / g g z .2019 .1 .10}$

\section{«Республика Косово»: наркотеррор регионального и глобального уровня}

\author{
А. И. Филимонова, \\ С. А. Чередниченко \\ Московский гуманитарный университет
}

Статья представляет собой анализ криминальной активности албанских кланов на территории Косово и Метохии (самопровозглашенного террористического формирования «Республики Косовы») в сфере наркоторговли. Интересы албанских наркосиндикатов срастились с квазигосударственными, политическими и международными структурами на территории Космета, которая разделена на зоны ответственности наркокриминальных группировок, во главе которых находятся занимающие ключевые «государственные» и политические посты командиры бывщей Армии освобождения Косово, а деятельность криминального подполья вышла далеко за предель региона.

Ключевые слова: Косово и Метохия; «Республика Косово»; насилие; терроризм; сепаратизм; наркотрафик; наркотики; наркосиндикать

\section{“Republic of Kosovo”: Regional and Global Drug Terror}

\author{
A. I. Filimonova, \\ S. A. Cherednichenko \\ Moscow University for the Humanities
}

The article analyzes the criminal activity of the Albanian clans in the territory of Kosovo and Metohija (the self-proclaimed terrorist formation the "Republic of Kosovo") in the field of drug trafficking. The interests of the Albanian drug syndicates have fused with quasi-state, political and international structures in the territory of Kosmet, which is divided into zones of drug criminal groups' responsibility. These groups are headed by commanders of the former Kosovo Liberation Army who occupy the key "state" and political posts. The activities of the criminal underground have gone far beyond the region.

Keywords: Kosovo and Metohija; "Republic of Kosovo"; violence; terrorism; separatism; drug trafficking; drugs; drug indices

\section{ВВЕДЕНИЕ}

Албанский вопрос перед европейскими правительствами был поставлен на Берлинском конгрессе 1878 г., основной целью которого являлось воспрепятствование расширению российского влияния на Балканах. Главным 
победителем на конгрессе стала Австро-Венгрия, под покровительство которой перешли православные балканские народы. Одновременно с этого момента ведет отсчет особый интерес, проявляемый Веной к албанскому фактору. На Берлинском конгрессе был представлен Меморандум Призренской лиги, в котором от великих держав требовалось признание албанского национального идентитета и автономии в рамках Османской империи. Это был первый манифест о создании «Великой Албании», который стал платформой деятельности албанских националистов, основанный на идее албанского экспансионизма и панисламизма. Гарантом реализации требований Меморандума, означающих в перспективе создание независимого албанского государства, указывалась Великобритания - наиболее заинтересованная сторона в установлении барьера «славянской экспансии», которым стала бы независимая Албания.

Главной стратегической целью для Сербии в Первой Балканской войне (8 октября 1912 г. - 30 мая 1913 г.) являлось получение выхода к Адриатическому морю. Однако содержание Лондонского мирного договора (30 мая 1913 г.) зафиксировало положение, при котором самые большие потери по сравнению с остальными христианскими государствами - членами союза против Порты в аспекте раздела возвращенных территорий нес главный победитель в войне - Сербия. Лондонский мир, при заключении которого роль великих держав являлась ключевой, во-первых, установил новые границы между балканскими союзниками, с одной стороны, и Оттоманской империей - с другой, во-вторых, создал албанское государство. На последнем пункте особенно настаивала Австро-Венгрия, которая зашла настолько далеко, что требовала присоединения к независимой Албании Призрена ${ }^{1}$ и Печи ${ }^{2}$, и лишь вмешательство России вынудило передать их Сербии. Так с конца XIX в. начала XX вв. албанское государство не стало результатом автохтонного развития албанской национальной идеологии и национально-освободительного движения, но явилась итогом балканской политики великих держав, прежде всего, Австро-Венгрии и Великобритании, для которых формирование албанского государства и албанской нации являлись антитезой российскому влиянию в геополитическом и «антинацией» сербам в национальном аспектах.

В составе Сербии и Черногории, затем в югославском государстве экспансия албанского этнического корпуса сопровождалась насилием против сербского населения, терроризмом, террором и криминалом как средством осуществления политических целей, которые достигают пика в период военной агрессии НАТО против СРЮ. Этническая гомогенизация албанцев завершилась в 2008 г. нелегитимным провозглашением на территории Автономного края Косово и Метохии Республики Сербии независимой «Респуб-

\footnotetext{
${ }^{1}$ Призрен - столица средневекового сербского государства в период правления царей Душана и Уроша, получивший народное название «сербский Царьград».

2 Печ - исторический центр Сербской Православной церкви, центр Сербской архиепископии с 1253 г., с 1356 г. - Печская патриархия.
} 
лики Косовы». Однако проект не останавливается на данном этапе, он подразумевает создание этнически чистой «Великой Албании» с Косовом как государственно-политическим центром территорий Балканского полуострова, населенных албанцами и генератором выработки всего арсенала средств в осуществлении цели.

\section{АРМИЯ ОСВОБОЖДЕНИЯ КОСОВО}

В конце 1990-х гг. для реализации албанских сепаратистских устремлений на территории Косово и Метохии послужили паравоенные формирования карательно-диверсионного характера, главным из которых была Армия освобождения Косово (АОК, УЧК - Ushtria Çlirimtare e Kosovës, от алб. UÇK). Фактически АОК была сформирована в 1993 г. в районе Дреница (центральная часть Косово к западу от Приштины) на конференции общего совета т. н. Народного движения Косово (НДК), во главе армии стали Хашим Тачи и Джеват Халити. Относительно Халити уже тогда были известны его близкие связи с албанской спецслужбой Сигурими. Официальное создание Армии освобождения Косово стало отправной точкой терминальной фазы террористической борьбы за насильственное отделение Косово от Сербии. В состав Главного штаба АОК в разные периоды входили:

- глава Генштаба Агим Чеку;

- главнокомандующий Сулейман Селеми;

- глава Отдела по логистике Джеват Халити;

- глава Отдела по военным операциям Реджеп Салими;

- глава разведслужбы Кадри Весели;

- глава Отдела информации, позднее переформированного в Отдел по политическим вопросам, Хашим Тачи;

- начальник Управления полиции Фатмир Лимай.

Спецификой деятельности АОК являлось сращение террористической и криминальной активности. Главари АОК одновременно являлись лидерами криминальных группировок, «ответственных» за определенные зоны на территории Косово, действующих по сей день и поддерживающих экстремально высокий уровень деструктивного потенциала не только в балканском, но и европейском регионе. Криминальные силы в Косово приобрели настолько мощный размах, что, как отмечает известный французский криминолог ЖанФрансуа Гейро, «работает почти совершенная лаборатория создания девиантных государств как части криминального корпуса новой Европы» (Kriminalci vladaju Balkanom, 2012: Электронный ресурс; здесь и далее пер. наш. - A. Ф., С. Ч.). Средства криминальных группировок от торговли наркотиками, оружием и людьми являлись самым надежным способом финансирования АОК и албанского сепаратизма.

\section{АЛБАНСКИЙ КРИМИНАЛИТЕТ}

Основным средством дохода «Республики Косовы» является наркотрафик. Его возникновение и развитие относится к завершающему этапу существованию СФРЮ. Тогда, в начала 1980-х гг., албанская контрабанда нарко- 
тиков осуществлялась по маршруту из Ближнего Востока через Балканы в Европу и США и проявлялась лишь спорадически. В тот период албанцы были лишь курьерами, наемниками преимущественно у турецкой наркомафии и болгарских криминальных структур. Однако по мере роста албанского сепаратизма в Космете, расширения влияния албанских эмигрантских групп и особенно поддержки со стороны внешнего фактора начали оформляться самостоятельные албанские наркомафиозные структуры. Коренное изменение статуса албанских наркокланов произошло в конце 1990-х гг., когда Госдеп США приступил к реализации своих многоуровневых геостратегических целей на Балканах, одним из инструментов достижения которых были избраны албанские криминальные группировки. Помощь албанскому сепаратизму была оказана всесторонняя: дипломатическая, экономическая, военная (вплоть до нанесения воздушно-бомбовых ударов по СРЮ), албанскому криминалу был предоставлен карт-бланш на деятельность как на Балканах, так и в Европе. Разведка Управления по борьбе с наркотиками США (Drug Enforcement Administration, DEA) весной 1999 г. приводила сведения, что группы косовских албанцев, «ответственные» за транспортировку наркотиков, находятся на втором месте на балканском маршруте, сразу после турецких (Радосављевић, 2010: Электронный ресурс).

В настоящий момент албанские наркокриминальные структуры уверенно движутся в направлении усиления своего влияния в разных государствах региона и мира. Различные организации по борьбе с организованной преступностью - ФБР, Интерпол и Европол - свидетельствуют, что албанская мафия стала самой серьезной криминальной организацией в Европе, поскольку контролирует большую часть торговли героином во многих европейских странах.

Балканские наркокоридоры подразделяются на два главных потока: северный героиновый («золотой полумесяц»: Афганистан - Пакистан, далее Турция - Венгрия - Румыния) и южный кокаиновый (Турция - Греция Македония - Албания - Италия). Центром «Балканского маршрута» является Косово и Метохия. По различным оценкам, в настоящий момент албанская мафия контролирует около 75 \% трафика героина на западноевропейском наркорынке и до половины совокупного количества героина, продаваемого в США. За поставки героина в Европу отвечают около 30 албанских наркокланов, каждый из которых контролирует «свой» участок наркотрафика. В территорию, через которую идет наркотрафик, превращена почти все Косово (за исключением четырех северных общин - Зубин Поток, Звечан, Лепосавич, северная Косовская Митровица, населенных сербами). Албанские кланы в Космете ежемесячно осуществляют оборот героина в размере от 4 до 6 тонн, стоимость годового оборота только героина - 2 млрд долларов. Деньги от наркоторговли отмываются посредством более двухсот частных банков, а также через сеть салонов красоты, парфюмерных магазинов, кафе и т. п., открытых в Италии, Испании, Великобритании и в других странах Западной Европы. 
Канал-трансфер наркотиков из Турции в Италию проходит через Тропой, порты Дуррес и Валону (Албания). В Албании также находятся лаборатории по переработке сырья и производству кокаина и героина, направляемого затем в Лужане, Муховац и Велики Трновац на юге Сербии, а также в Тузи и Ульцинь в Черногории. Крупные центры оборота наркотиков находится в Македонии - Гостивар, Куманово и Скопье. С территории этих трех стран наркотики распространяются по всей Европе. Передача наркотиков, оружия и других контрабандных товаров происходит на официальных пограничных пунктах (главным образом, Тропой), благодаря сотрудничеству преступных групп с персоналом таможни.

Преступная деятельность в КиМ осуществляется семейными кланами - фисами, каждый из которых контролирует определенную часть территории Космета. Сферы влияния поделены на три основные зоны: Дреница, Дукаджин и Лаб, в которых лидерами преступной активности являются бывшие полевые командиры АОК, в настоящий момент действующие главы наркокримиальных фисов и ключевые политические фигуры «Республики Косовы».

Так, контролем стратегической дороги, соединяющей Черногорию и Македонию через Призрен, Клину и Исток, занимается Дреницкая группировка во главе с Хашимом Тачи (бывший лидер Демократической партии Косово, передавший свой пост Кадри Весели после победы на президентских выборах в 2019 г., ныне пятый президент «Республики Косовы»). Группа занимается незаконной продажей наркотиков, оружия, сигарет, крадеными автомобилями, топливом, а также торговлей «белыми рабами», т. е. людьми. Семья Тачи тесно связана с албанской, македонской, болгарской и чешской мафией. В данном районе «работают» также фисы Лука и Селими, занимающиеся всевозможной контрабандой.

В настоящий момент в состав Дреницкой группировки, помимо Тачи, входят не менее печально известные личности в Косово, ныне занимающие весьма солидные посты: председатель «косовского парламента» Кадри Весели, «вице-премьер косовского правительства» и глава переговорной группы по линии Приштина - Белград Фатмир Лимай и один из руководителей албанской разведки K-SHIK Джеват Халити. Спецдокладчик Совета Европы Дик Марти в своем докладе, посвященном организованной преступности в Косово (2010), приводит данные о том, что члены Дреницкой группы Джавит Халити, Кадри Весели, Азем Суля, Хашим Тачи и Фатмир Лимай были непосредственно вовлечены, а в ряде случаев лично приказывали и контролировали убийства, похищения и пытки в различных частях Косово в период с 1998 по 2000 гг. Аналитики стран НАТО пришли к выводу о том, что за мощным криминалом в Косово стоит Хашим Тачи. Именно Тачи в докладах спецслужб Германии (Федеральная разведывательная служба Германии, BND), Италии (Агентство информации и внешней безопасности, AISE), Beликобритании (МИ-5), Греции (Национальная служба разведки, ЕҮП) назван наиболее опасным главарем мафии и командиром АОК. Дик Марти указывает: связи Тачи с организованным криминалом начались задолго до начала го- 
рячей фазы конфликта в Косово, а Дреницкая группа постепенно поставила под свой контроль остальные группировки тогда разрозненного сепаратистского движения, с 1998 г. она становится головной организацией для большинства ОПГ Албании, членами которых были косовские албанцы. В течение последующего за конфликтом десятилетия Тачи и члены его Дреницкой группы установили жесткий контроль над героиновым наркотрафиком и торговлей другими наркотиками (Marty, 2010: 15).

На территории Печи, Дечан и Чаковицы, расположенных в районе Дукаджин, действует так называемая Метохийская группа под руководством Рамуша Харадиная (лидер Альянса за будущее Косово, премьер-министр «Республики Косово»). Семья Харадинай также занимается незаконным оборотом наркотиков, оружия, акцизными товарами, крадеными транспортными средствами, а также вымогательством у албанского населения в КиМ. Контрабандный товар переправляется в Македонию, южную Сербию и Черногорию по дороге Печ - Кула - Рожае. Благодаря тесной связи Рамуша с бывшими командирами АОК, которые после демилитаризации были переведены в Корпус защиты Косово (КЗК, с 1999 по 2009 гг., с 2009 по 2018 гг. - Силы безопасности Косово, с 2018 г. - Армия Республики Косово) и Косовские полицейские силы (КПС), осуществляется по-военному четкая переброска контрабанды. В данном регионе также «работает» фис Келменди, в районе Чаковицы особенно активен клан Бабалия, сотрудничающий с кланом Харадинай.

На территории Лаба, включая Гнилане, Витину и Качаник, существует «группа Реми» под руководством Рустема Мустафы (бывший лидер АОК, был осужден и приговорен к нескольким годам лишения свободы), тесно связанного с семьей Харадинай. Клан Сума, связанный с «группой Реми», работает в Качаницком районе. Кроме рэкета и шантажа, он занимается контрабандой оружия и наркотиков из Македонии в КиМ и в обратном направлении.

Помимо наркотрафика, на территории КиМ также зафиксирована незаконная торговля оружием, акцизными товарами, украденными автомобилями, контрабанда рабов и «черная трансплантология» - торговля человеческими органами. Рэкет, шантаж и насилие в отношении членов своей же национальной албанской общины в Косово, а также албанцев, занимающихся временной работой за границей, являются «визитной карточкой» организованной преступности. Запугивание и изгнание сербов и другого неалбанского населения с территории КиМ (этнические чистки) также являются легким источником дохода, поскольку от продажи заброшенного жилья и вынужденно продаваемых участков земли (а именно сербам принадлежит подавляющая часть земли в КиМ) поступает огромная прибыль. Бывшие лидеры АОК таким образом финансируют независимость и самостоятельность «Республики Косовы».

Кровнородственно-криминальные фисы являются не теневой, а единственной реальной политической и иной властью, обладающей своей спецслужбой K-SHIK, спонсируемой напрямую ЦРУ. Преступный косовский мир 
тесными семейными узами связан со своими иностранными «коллегами». Кроме того, албанские наркосиндикаты скоординированы с местными квазигосударственными органами и политическими структурами настолько близко, что невозможно провести границу где заканчивается одни и начинаются другие.

Самая большая концентрация криминальных группировок - в Приштине, это кланы Мустафа, Реми, Келменди, Лука, Халити, Рамадани, Шабанай, Марай, Мальоку и Гецай-Селими. Однако в компетенцию каждого клана могут входить и несколько зон - это семьи Лука, Реми, Гецай и Селими. Совпадение зон ответственности фисов и прежних зон ответственности АОК показывает, что последняя выпестовалась из существующих организованных групп, после формального роспуска с прибытием международных сил она вновь влилась в состав криминальных формирований.

В настоящий момент Хашим Тачи является ключевым рычагом для решения политических задач. Однако в определенной степени антитезой ему является более авторитетный с организационной и военной точки зрения Рамуш Харадинай. Разница между ними заключается в том, что Тачи склонен к определенным компромиссам ради удержания власти, постепенно он превращается в политического «белого воротничка», в то время как Харадинай представляет традиционную непреклонную албанскую националистическую линию. Тачи контролирует более широкую и мощную криминальную сеть на большей части Косово (в основном по линии Приштина - Глоговац Србица - Клина - Ораховац - Призрен). Рамуша Харадиная - с албанской точки зрения «прокаленного в боях командира» - поддерживает подавляющее большинство бывших командиров АОК (значительная часть которых так или иначе оказалась в составе созданной в обход Резолюции СБ ООН 1244 «Армии Косово»), финансовую помощь ему оказывает клан Лука из Печи, что позволяет ему контролировать направление Печ - Дечани Джаковица. Однако и Тачи, и Харадинай одновременно являются фаворитами крупнейшего наркобосса Джавита Халити, а также международных факторов и структур в Косово (KFOR, UNMIK, EULEKS) и, по сути, в нужные моменты разыгрывают роли «хорошего» и «плохого» полицейского в отношении Сербии, целью игры остается константа: признание «Республики Косово» со стороны Сербии и получение членства в ООН.

Отношения между фисами регулируются обычным правом, восходящем к Закону Леки Дукаджини (XV век), включающим, помимо прочего, кровную месть и «кодекс мафии», прежде всего, омерту. При этом позитивные нормы закона рассматриваются как секундарные, т. е. неважные и необязательные. Основное правило всех кланов — кровная месть в случае предательства. Пункт Закона Леки Дукаджини был включен в присягу АОК: «...Если нарушу присягу, пусть меня накажут самой строгой законной военной казнью, а если совершу предательство, пусть прольется моя кровь. Клянусь» (цит. по: Бериша, 2012: 245). 
Особенно тесное сотрудничество албанские фисы поддерживают с зарубежными группировками из Турции, Албании, Болгарии, Македонии, поскольку на территории этих стран проходят транзитные наркопути.

Внутриклановые отношения характеризуются чрезвычайно строгой иерархией и дисциплиной, которая достигается с помощью системы наказаний за любое отклонение от обычаев и правил, страх от неотвратимого наказания гарантирует безоговорочную лояльность. Поскольку фисы строго привязаны к определенной территории и основаны на кровном родстве, это ограничивает число его членов и исключает возможность оперативного внедрения агентов спецслужб и полиции. Как правило, главари кланов способны к достижению быстрых и гибких договоренностей с криминальными организациями или представителями других стран, однако в «бизнес» фиса члены других национальных группировок допускаются только как исполнители одноразовых и второстепенных задач. В целом криминальная иерархия мафиозных семей включает, как правило, 3-4 уровня, так что даже при нейтрализации одного или нескольких глав клан продолжит эффективно функционировать. Организация подобного рода позволяет албанским криминальным группам планировать и осуществлять масштабные и сложные операции во всех областях «делового интереса», используя военный опыт, полученный на войнах прошлых лет, и оперативный опыт, вынесенный из деятельности собственных и албанских спецслужб, а также современные технологии и средства. Кроме того, поскольку у косовских албанцев очень сильно развита идентичность, основанная на коллективной принадлежности, данный сегмент самосознания способствует связи организованного криминала с идеями паналбанизма, панисламизма и террористической деятельностью.

Несмотря на то, что кланы стратифицировали территории по зонам своей ответственности, периодически между ними возникают конфликты, основанные на политической и конкурентной почве. Иногда подобные конфликты приводят к масштабной кровной мести, которая распространяется на всех членов враждующих семей. Например, ссора между семьями Мусай и Харадинай, возникшая в результате попытки семьи Мусай перехватить под свой контроль часть «бизнеса» Харадинаев, привел сначала к убийству Синана Мусая, ранению Рамуша Харадиная, а позднее - к полному истреблению клана Мусай. Столь непримиримая жестокость борьбы в первую очередь обусловливается огромной прибылью от наркопотока.

В целом на территории бывшего автономного края Косово и Метохия, объявленного сепаратистами «Республикой Косова» (кроме сербского севера), деградировало все, кроме процветающей организованной преступности. Экстремистские группы АОК ликвидировали всех своих политических противников, заставляя собственное албанское население жить в атмосфере постоянного страха. Представители Совета Европы регулярно сообщают о зашкаливающем уровне коррупции, отмывании денег, экономических преступлениях, неэффективности финансовых учреждений и налоговой политики. Косовские суды не отвечают современным требованиям, число судей и прокуроров невелико, заработная плата недостаточна для обеспечения их неза- 
висимости, суд находится под сильным политическим давлением, даже личная безопасность персонала судебной системы не может быть гарантирована. Организованный криминал превратился в теневое, но реальное правительство.

За спиной у албанских наркокланов в Косово и Метохии - две американские военные базы «Бондстил» и «Малый Бондстил», а также полный комплекс поддержки со стороны США и Евросоюза - от дипломатической до масс-медийной и военной. США сыграли решающую роль в начале вооруженной агрессии НАТО 1999 г. на стороне косовских сепаратистов, целью которой, как образно отмечает в бытность свою немецкий депутат, госсекретарь и вице-президент Парламентской ассамблеи ОБСЕ Вили Вимер, еще в 1980-х гг. ставилось «создание независимого Косово в качестве сухопутного авианосца США», стремившихся к доминированию на Балканах (Вили Вимер ... , 2019: Электронный ресурс).

Тачи, Халити, Весели, Суля, Лимай за последние годы подвергались судебным преследованиям за военные преступления или участие в совместном преступном деянии, расследование вели Международный трибунал по бывшей Югославии, Администрация ООН по Косову (United Nations Interim Administration Mission in Kosovo, UNMIK), Европейская миссия права в Косово (European Union Rule of Law Mission in Kosovo, EULEX). Однако вместо тюремного заключения главари АОК и наркомафии находятся на свободе, более того, и поныне являются ключевыми общественными и политическими фигурами. Хотя в Космете общеизвестен факт: избежать суда им удалось благодаря запугиванию и физическому устранению свидетелей и нежелание «международной общественности» наказывать тех, кто является экспонентом их политики и кого они поддерживают по сей день.

После Косово удар нацелен на юг Сербии (общины Прешево, Буяновац, Медвежья с большинством или значительной частью албанского населения) с перспективой получения контроля над стратегическим направлением, связующем Космет, Македонию, Сербию и Болгарию с выходом на Грецию и Центральную Европу. Одним из главных дистрибутивных центров всего Балканского полуострова является село Велики Трновац (община Буяновац, на административной границе с Косово, население - около 10 тыс. человек, исключительно албанцы). Велики Трновац находится также вблизи от границ с Болгарией, Албанией и Македонией, этот населенный пункт - настоящий «перекресток наркомагистралей». Через него идет героиновый поток из Афганистана, Пакистана, Ирана и Турции. Здесь находятся склады и идет упаковка «товара». По некоторым оценкам, ежегодный оборот наркотических веществ, осуществляемый через Трновац, составляет около 50-60 тонн героина, который через Албанию и Черногорию поступает в Италию, частично оседает в Сербии и далее поступает в другие западноевропейские страны.

Велики Трновац недаром называют «героиновыми воротами Запада». В процесс дистрибуции героина вовлечено все (албанское) население региона - около 6 тыс. человек. Интерпол отмечал, что там постоянно готово к продаже по меньшей мере три тонны героина. Итальянский Центр по борьбе с 
мафией указывал, что 70 \% наркотиков, предназначенных для западноевропейского рынка, идет через Прешево и Трновац, а весь процесс контрабанды контролируют семейные кланы Османи, Халифи и Буньаку. Итальянцы отмечали, что регион крайне криминализирован, а сербские власти адекватно ситуации не реагируют. При этом сами сербские полицейские отмечают особые трудности, связанные с пресечением преступной деятельности, связанной с наркобизнесом. В нем действуют исключительно семейно-клановые связи, поэтому внедрение или инсайдерская информация практически невозможны. Организация поставлена настолько «хорошо», что для полиции даже приблизиться к Велики Трновцу представляет проблему (Телесковић, 2009: Электронный ресурс).

Западную часть Македонии и часть Косово контролирует клан Тачи. Председатель македонской Демократической партии албанцев Мендух Тачи непосредственно связан с мафией, контролирующей такие сферы, как оборот героина, кокаина и автомобилей. В Македонии около Куманово находится и одна из крупнейших фабрик по производству героина. В Албании наиболее влиятелен клан Бериша, он «охватывает» и часть Метохии. Не меньшую опасность представляет собой наркоклан семейства Кула, контролирующий наркооборот из Турции, поставки оружия и нелегальных мигрантов; клан Абазии (наркотики и проституция в «сотрудничестве» с итальянским криминалом); Брокай (его основу составляют бывшие работники спецслужб и политики, их «сфера» - наркотики, оружие, проституция). По сути, весь регион - Албания, Косово и Западная Македония — является одним большим наркоскладом.

Около 80 \% венгерского рынка героина также находятся в руках албанской мафии, продает она в основном также героин из Турции и Афганистана. По данным словацкой полиции, почти 100 \% героина в Словакию поступает из Афганистана «балканским трафиком» через Косово, Македонию и Албанию. В последнее время албанские группировки прибирают к рукам порты Румынии. Основная прибыль от наркобизнеса идет для «Республики Косовы», при этом большая часть денег тратится в Италии, где закупается оружие. В Италии за краткое время албанской наркомафии удалось потеснить турецкую. Из курьеров албанцы стали организаторами наркосети и партнерами сицилианской Koza Nostra, неапольской Kamori и калабрийской N'dragenti. Италия является одной из главных опорных баз албанских криминальных структур, через руки которых проходит около 50 кг героина ежедневно. Милан — это «бизнес-центр», но область Калабрия — центр торговли наркотиками и оружием. На границе Италии и Швейцарии наркотрафик контролируют албанцы.

Не менее важным «опорным пунктом» в Европе является Швейцария - отсюда начиная с конца 1990-х гг. финансировалась «балканская смерть» - террористические албанские армии. Центр «черной биржи» торговли оружием находится в Берне и Базеле. В Швейцарии особо известен клан Османи, главарь которого — Чазим («Феликс»). Помимо доходов от наркотрафика, работорговли и остальных видов организованной преступности, клан пользу- 
ется финансовой поддержкой крупнейшего албанского «бизнесмена» из Косово Бехджета Пацолли.

В Швеции и Норвегии албанцы контролируют 80 \% наркоторговли, албанцы из Косово уже десять лет остаются главными дистрибьютерами на греческом рынке кокаина, героина и марихуаны. Греческий трансфер албанцы используют для поставок мигрантов-албанцев и нелегалов из Турции, Пакистана, Шри-Ланки, Китая и т .д., которые также являются курьерами по доставке наркотиков. Таким же коридором является Адриатическое море, связующее побережья Италии и Албании. Методы, применяемые албанскими наркокриминальными группировками, крайне агрессивны, это олицетворение «криминала воинствующего», который превратился в ночной кошмар полицейских подразделений любой страны.

\section{ЗАКЛЮЧЕНИЕ}

В феврале 2019 г. британская газета Daily Mirror привела сведения о том, что косовско-албанская (шиптарская) мафия взяла под свой полный контроль рынок кокаина в Великобритании. «Успеху» албанской наркомафии в первую очередь способствовала миграция албанцев после падения коммунистического режима в Албании в 1990 г., которые усилили существующие к тому времени албанские ОПГ в Туманном Альбионе, отбросили посредников и установили прямую связь с колумбийскими наркокартелями. Это позволило снизить цену и увеличить «чистоту товара», тем самым вовлекая в наркозависимость все более широкие слои английской молодежи. Кроме того, албанская наркомафия оказывает сильное влияние на другие ОПГ в Великобритании и связана с группировками, специализирующимися на отмывании денег и торговле людьми (Albanska mafija ..., 2019: Электронный ресурс). Тем самым Великобритания, с XIX в. осуществляющая политику ослабления сербских самостоятельных государств на Балканах, видя в них «оружие России», в конце XX - начале XXI вв. представляя всемерную поддержку косовскому сепаратизму, сама столкнулась с угрозой безопасности, на ликвидацию которую ей потребуется бросить все силы, но при совершенно неизвестном исходе.

Так разрешение косовского кризиса путем агрессии НАТО против Югославии под предлогом «гуманитарных соображений» или же «мер по принуждению к миру», дало свои весьма специфические плоды. Истинным победителем стали не албанцы, не международное сообщество, а криминал, исламизм и терроризм. Наркосиндикаты празднуют триумфальную победу и экстремальную выгоду. Албанские наркокланы утвердились на региональном балканском уровне и вышли далеко за его пределы. Для США, Евросоюза, а также для Российской Федерации деятельность албанских наркокриминальных групп являет собой угрозу, подрывающую основы национальной безопасности. 


\section{СПИСОК ЛИТЕРАТУРЫ}

Бериша, Х. (2012) Политичко насиље на Косову и Метохији од 1945. до 2003. године : докт. дис. / Београдски универзитет, факултет политичких наука. Београд. 476 с. URL: http://nardus.mpn.gov.rs/handle/123456789/3075 [архивировано в WaybackMachine] (дата обращения: 25.02.2019).

Вили Вимер: Косово као држава планирано од краја 80-их, његова једина функција је да буде «амерички носач авиона» (2019) [Электронный pecypc] // Српски став. 25 февраля. URL: https://srpskistav.com/prenosimo/ вили-вимер-косово-као-држава-планиран/ [архивировано в WaybackMachine] (дата обращения: 25.02.2019).

Радосављевић, Е. (2010) Марти завртео и точкове истраге! [Электронный ресурс] // Вечерње новости. 18 декабря. URL: http://www.novosti.rs/вести/ насловна/досије.407.html:311914-Marti-zavrteo-i-tockove-istrage [архивировано в WaybackMachine] (дата обращения: 25.02.2019).

Телесковић, Д. (2009) Царство хероина у Великом Трновцу [Электронный ресурс] // Политика. 9 мая. URL: http://www.politika.rs/scc/clanak/86250/ Hronika/Carstvo-heroina-u-Velikom-Trnovcu [архивировано в WaybackMachine] (дата обращения: 25.02.2019).

Albanska mafija preuzela britansko tržište kokaina vredno pet milijardi funti (2019) [Электронный ресурс] // Вечерње новости. 25 февраля. URL: http://www.novosti.rs/ vesti/planeta.299.html:779367-Albanska-mafija-preuzela-britansko-trziste-kokaina-vrednopet-milijardi-funti [архивировано в WaybackMachine] (дата обращения: 25.02. 2019).

Kriminalci vladaju Balkanom (2012) [Электронный pecypc] // Vesti online. 19 июня. URL: https://vesti-online.com/Vesti/Hronika/233286/Kriminalci-vladaju-Balkanom- [архивировано в WaybackMachine] (дата обращения: 25.02.2019).

Marty, D. (2010) Inhuman treatment of people and illicit trafficking in human organs in Kosovo. AS/Jur (2010) 46. 12 December. 27 р. [Электронный реcypc] // PACE. URL: https://assembly.coe.int/CommitteeDocs/2010/ajdoc462010 prov.pdf [архивировано в WaybackMachine] (дата обращения: 25.02.2019).

Дата поступления: 26.02.2019 г.

\section{REFERENCES}

Beriša, H. (2012) Politichko nasise na Kosovu i Metokhiji od 1945. do 2003. godine [Political violence in Kosovo and Metohija from 1945 till 2003] : $\mathrm{PhD}$ diss. / University of Belgrade, Faculty of Political Sciences. Belgrade. 476 p. [online] Available at: http://nardus.mpn.gov.rs/handle/123456789/3075 [archived in WaybackMachine] (accessed 25.02.2019). (In Serb.).

Vili Vimer: Kosovo kao drzhava planirano od kraja 80-ikh, њegova jedina funktsija je da bude «americhki nosach aviona» [Willy Wimmer: Kosovo as a state has been planned since the late 80s, its only characteristic is to be an "American aircraft carrier"]. (2019) Srpski stav, February 25. [online] Available at: 
https://srpskistav.com/prenosimo/вили-вимер-косово-као-држава-планиран/ [archived in WaybackMachine] (accessed 25.02.2019). (In Serb.).

Radosavљеvih, Е. (2010) Marti zavrteo i tochkove istrage! [Marty has spinned the wheel of investigation as well!]. Vecherme novosti, December 18. [online] Available at: http://www.novosti.rs/вести/насловна/досије.407.html:31 1914-Marti-zavrteo-i-tockove-istrage [archived in WaybackMachine] (accessed 25.02.2019). (In Serb.).

Teleskovih, D. (2009) Tsarstvo kheroina u Velikom Trnovtsu [The realm of heroin in Veliki Trnovac]. Politika, May 9. [online] Available at: http://politika.rs/scc/clanak/86250/Hronika/Carstvo-heroina-u-Velikom-Trnovcu [archived in WaybackMachine] (accessed 25.02.2019). (In Serb.).

Albanska mafija preuzela britansko tržište kokaina vredno pet milijardi funti [The Albanian mafia took control of the British cocaine market worth five billion pounds]. (2019) Vecherme novosti, February 25. [online] Available at: http://www.novosti.rs/vesti/planeta.299.html:779367-Albanska-mafija-preuzelabritansko-trziste-kokaina-vredno-pet-milijardi-funti [archived in WaybackMachine] (accessed 25.02.2019). (In Serb.).

Kriminalci vladaju Balkanom [Criminals rule the Balkans]. (2012) Vesti online, June 19. [online] Available at: https://vesti-online.com/Vesti/Hronika/ 233286/Kriminalci-vladaju-Balkanom- [archived in WaybackMachine] (accessed 25.02.2019). (In Serb.).

Marty, D. (2010) Inhuman treatment of people and illicit trafficking in human organs in Kosovo. AS/Jur (2010) 46. 12 December. 27 p. PACE. [online] Available at: https://assembly.coe.int/CommitteeDocs/2010/ajdoc462010prov.pdf [archived in WaybackMachine] (accessed 25.02.2019).

Submission date: 26.02.2019.

Филимонова Анна Игоревна — кандидат исторических наук, доцент кафедры международных отношений и дипломатии факультета международных отношений и туризма Московского гуманитарного университета. Адрес: 111395, г. Москва, ул. Юности, 5, корп. «В», каб. 208. Тел.: +7 (499) 374-9210. Эл. адрес: annafilimon@yandex.ru

Чередниченко Сергей Александрович - студент 4 курса факультета международных отношений и туризма Московского гуманитарного университета. Адрес: 111395, г. Москва, ул. Юности, 5, корп. «В», каб. 208. Тел.: +7 (499) 374-92-10. Эл. адрес: intrelation@mosgu.ru

Filimonova Anna Igorevna, Candidate of History, Associate Professor, Department of Foreign Relations and Diplomacy, Faculty of International Relations and Tourism, Moscow University for the Humanities. Postal address: Office 208, Bldg. "B”, 5 Yunosti St., 111395 Moscow, Russian Federation. Tel.: +7 (499) 37492-10. E-mail: annafilimon@yandex.ru 
Cherednichenko Sergey Aleksandrovich, 4th-year student, Faculty of International Relations and Tourism, Moscow University for the Humanities. Postal address: Office 208, Bldg. "B”, 5 Yunosti St., 111395 Moscow, Russian Federation. Tel.: +7 (499) 374-92-10. E-mail: intrelation@mosgu.ru

Для цุитирования:

Филимонова А. И., Чередниченко С. А. «Республика Косово»: наркотеррор регионального и глобального уровня [Электронный ресурс] // Горизонты гуманитарного знания. 2019. № 1. C. 171-184. URL: http://journals. mosgu.ru/ggz/article/view/957 (дата обращения: дд.мм.гггг). DOI: 10.17805/ ggz.2019.1.10 